\title{
Impact of investments on the economy of the Republic of Uzbekistan and the importance of its geographical location
}

\author{
Madina Raimjanova ${ }^{1,{ }^{*}, \text { Lola Sabirova }}{ }^{1}$, Nodira Khanova $^{1}$, Shoira Asamkhodjaeva ${ }^{1}$, and \\ Kodir Nosurullaev ${ }^{2}$ \\ ${ }^{1}$ Tashkent Institute of Finance, 100000, 60A, A. Temur Street, Tashkent, Uzbekistan \\ ${ }^{2}$ Tashkent institute of irrigation and agricultural mechanization engineers, 100000, 39, Kari Niyazov \\ street, Tashkent, Uzbekistan
}

\begin{abstract}
The key to successful innovative development of the Republic of Uzbekistan is the formation of new innovative high-tech industries, the upgrading of technical and technological nature, the input of modern facilities, expansion of production volume, ready to compete, the increase in exports in parallel with the filling of the domestic market finished products with high added value. The Republic of Uzbekistan is an attractive place for investment, due to a wide sales market and a developed transport infrastructure integrated into the multi-modal communication system of Eurasia, which contributes to determining the future state of investment and trade and economic cooperation. Foreign investors who invest in Uzbekistan have the opportunity to enter the 5 largest and emerging markets-the CIS countries with a market of more than 300 million people, Central and Eastern Europe, South and South-East Asia, and the Middle East.
\end{abstract}

\section{Introduction}

After independence in 1991, the Republic of Uzbekistan decided to pursue an independent foreign economic policy aimed at achieving a real openness of the economy and integrating it into the global economic system. The participation of the Republic of Uzbekistan in international cooperation is determined by natural, economic, cultural, historical and other opportunities.

In today's world, innovative investments are important. They contribute to the improvement of the real sector of the country's economy and the formation of a new quality foundation for sustainable, long-term development of the economy.[1]

The main factor in the development and modernization of the country's economy is the formation of a favorable investment climate, stimulating the business community to large investments in the industry, knowledge-intensive and high-tech production.

Investment is a complex and dynamically active area in terms of legal regulation in modern economies. In particular, the legal provision of investment activities in the regions

\footnotetext{
${ }^{*}$ Corresponding author: indira91@inbox.ru
} 
of the Republic of Uzbekistan is important for creating conditions for socio-economic development and improving the standard of living of the population.

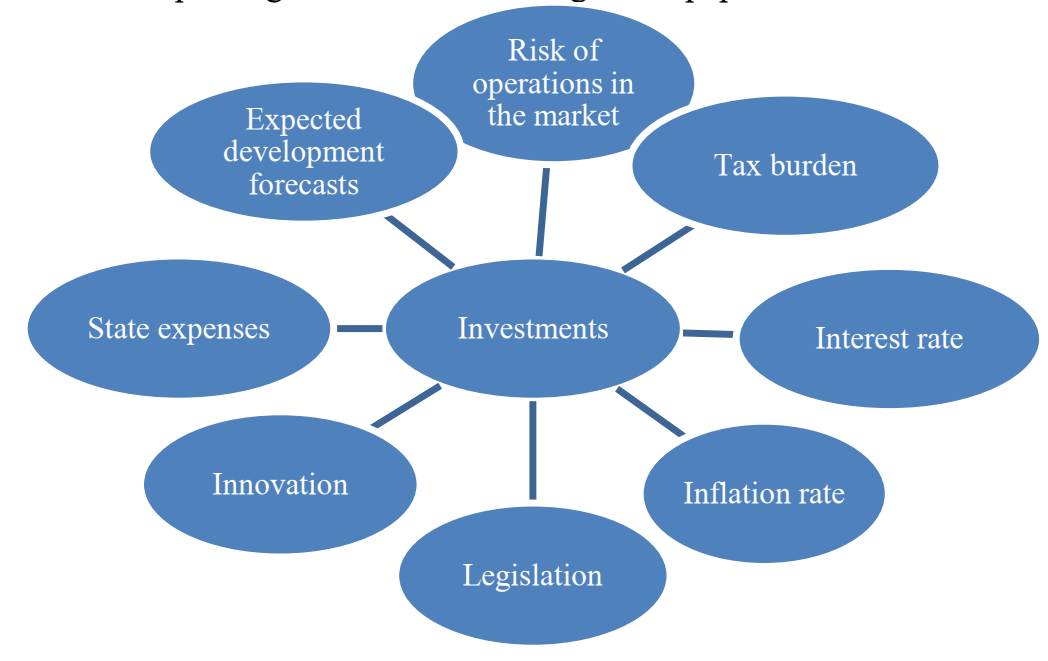

Fig. 1. Factors influencing investment decisions.

Against the background of increased local production and high investment activity, market processes are strengthening. The final goal of the investment policy is to develop investment activities that improve the country's economy and increase the efficiency of public production.

Foreign direct investment is important in determining the dynamics of economic growth, the depth and scale, as well as the speed of the process of change in the economic system at the local level. Foreign direct investment has a positive effect on the private sector, enterprises that have a share of foreign direct investment are distinguished by a high level of applied technologies, including managerial ones. Namely, Uzbekistan imports technologies, principles of corporate behavior, all this accelerates the process of market reform, the development of institutional infrastructure. [2]

The investment climate in the Republic of Uzbekistan is very stable. 2000 was considered a period of low investment activity, this was due to the internal problems of the Economy of Uzbekistan, and the pre-crisis situation on the world market. Between 2006 and 2009, the demand for investment resources began to increase, 2010-2011 is considered to be the years of rapid growth of investments in the economy of the Republic of Uzbekistan. At the end of 2011, foreign investment in Uzbekistan's economy was over \$6.7 billion. This increase in foreign investment indicates an improvement in Uzbekistan's investment climate, and an increase in investor interest and reliability in Uzbekistan's economy in recent years.[3]

International rating agencies assign Uzbekistan an assessment at the level of "stability", the number of banks suitable for this assessment is increasing every year. In recent years, the Republic of Uzbekistan has made progress in reforming the legislative and administrative system of the Republic.

In today's global economy, the following factors are taken into account:
a) progress of market reforms
b) degree of risk, including: transfer risks, risk of macroeconomic instability, legal risk
c) stability in politics
d) access to affordable factors of production (particularly low-cost labor)
e) Access to local market information
f) intellectual property control, sales strategy and product quality. 


\section{Methodology}

The aim of the study is to identify the measures necessary to attract foreign investment more actively to the country and its regions in general.

The methods of research for a deep and comprehensive study of the state and dynamic changes taking place in Uzbekistan in recent years in the area of creating a new investment climate in Uzbekistan, its state and prospects, and identifying the measures necessary to actively attract foreign investment to the country, the article uses methods of systematic approach, qualitative and quantitative comparative analysis.

The study of the material was carried out by methods of scientific abstraction, analysis and synthesis, mathematical and statistical methods.

In the Republic of Uzbekistan, foreign investment is carried out in such forms as:

$>$ Equity in charter funds and property of business entities

$>$ Formation and development of business entities wholly owned by foreign investors

$>$ Purchase of property, shares, securities, debts issued by residents of the Republic of Uzbekistan

$>$ The right to intellectual property

$>\quad$ Purchase of ownership of trade and services, living quarters together with the land on which they are located, and ownership and use of land and natural resources

Under the condition of an investment economy, the method of economic justification is constantly being modernized. In different countries, when conducting investment calculations, dynamic methods of assessing economic efficiency are widely used, in which cash receipts and payments that appear at different points in time are discounted to a single point in time, ensuring their relationship.[4]

\section{Result}

Various methods of assessing the economic efficiency of investments are used to analyze investment projects:

- assessment of the absolute efficiency of investments, this assessment is based on the difference in financial values of results and costs associated with the implementation of the investment project (Current value method, net discounted income method, annuity method -Net Present Value (NPV))

-assessment of the relative efficiency of investments, which is based on finding a relationship between the financial values of results and costs that interact with the implementation of an investment project (the method of internal profitability or profitability (Internal Rate of Return - IRR))

- Assessing the ratio of the net operating value of the project to the amount of total initial investment (net present value ratio method (NPVQ))

- Estimating the return time of investment, during which initial investment costs are recouped by the proceeds from the project (payback method - PB)

- assessment and selection of the optimal option from among the alternative, equal in production effect or artificially brought to the same conditions (method of estimated costs) [5]

Foreign direct investment can have a different impact on local investment, depending on the economic environment. Foreign direct investment is activating local investment through relationships between foreign and local firms, the creation of new products, services and the introduction of new technologies and knowledge. This process has a negative side, real local interest rates are rising, the cost of real local exchange rates increases.[6] 


\section{Discussion}

In the Republic of Uzbekistan, in 2017, the volume of investments in fixed assets, compared to 2010 , exceeded 4 times, by $107.1 \%$ more than in the previous year. In 2010 , the volume of investments amounted to 15338.7 billion UZS, and in $2017-60719.2$ billion UZS.

\section{Investment structure of the Republic of Uzbekistan for 2017}

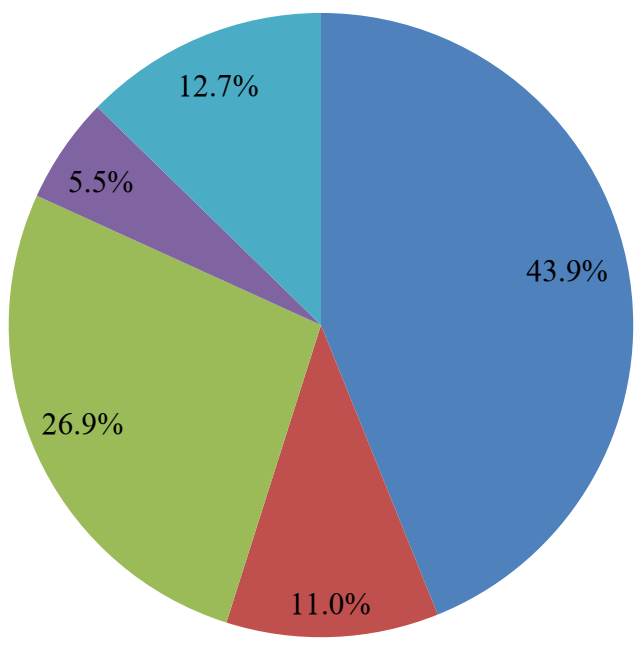

funds of enterprises and population

bank loans and other borrowed funds

Foreign investments and loans

- state budget funds

- extrabudgetary funds

Fig. 2. Investment structure for 2017.

According to data for 2010-2017, the volume of construction work increased by 4.7 points, more precisely from $105.1 \%$ to $109.8 \%$. The rapid growth of construction work was observed in 2012-2015, when their volume grew from $113.7 \%$ to $118.8 \%$. With such indicators, the living conditions of the population are markedly improved.[7]

The volume of private direct and other foreign investment in fixed capital in 2017 amounted to more than US\$ 2.4 billion, in particular the growth of private direct and other foreign investments. In the country's total investment, the share of direct investment increased from $15.3 \%$ to $20.4 \%$ in one year. The amount of funds of the Reconstruction and Development Fund of the Republic of Uzbekistan, developed strategic major investment projects on construction amounted to more than 1.0 billion U.S. dollars, with an increase of $84.8 \%$ compared to 2016 .[8]

The 2020 figures differ significantly from 2017 due to the impact of the virus on the economic system of the Republic of Uzbekistan. According to well-known data from January to September 2020, the total volume of foreign investments in the Republic of Uzbekistan amounted to $\$ 7.2$ billion (of these funds in fixed capital - $\$ 5.7$ billion), as well as included in them 4.9 billion dollars - foreign direct investment, and 2.3 billion dollars funds of international financial institutions and foreign government financial organizations [9].

As for foreign direct investment, industry enterprises have mastered 1.8 billion dollars of investments, of which $\$ 1.3$ billion in fixed capital, 3.1 billion dollars in regional investment programs, hence $\$ 2.5$ billion in fixed capital. 


\begin{tabular}{|l|l|}
\hline \multicolumn{2}{|c|}{2012} \\
\hline 158 & Comoros \\
\hline 159 & Suriname \\
\hline 160 & Mauritania \\
\hline 161 & Afghanistan \\
\hline 162 & Cameroon \\
\hline 163 & Togo \\
\hline 164 & Iraq \\
\hline 165 & Lao PDR \\
\hline 166 & Uzbekistan \\
\hline
\end{tabular}

\begin{tabular}{|l|l|}
\hline \multicolumn{2}{|c|}{2020} \\
\hline 63 & India \\
\hline 64 & Ukraine \\
\hline 65 & Puerto Rico \\
\hline 66 & Brunei Darussalam \\
\hline 67 & Colombia \\
\hline 68 & Oman \\
\hline 69 & Uzbekistan \\
\hline 70 & Vietnam \\
\hline 71 & Jamaica \\
\hline
\end{tabular}

Fig. 3. World Bank Doing Business ranking: 97 points improvement in the past 8 years.

The most attractive for foreign investors at the end of the reporting year were the electrical industry (the indicator increased 25 times in relation to 2019), the field of information and communication technologies (the indicator increased 3.6 times compared to 2019), and the chemical industry (the indicator increased by 1.2 times compared to 2019). High growth in foreign direct investment is observed in some areas of the Republic of Uzbekistan: Surkhandaryainskaya (1.1 times), Navoi (1.7 times), and Namangan regions (1.3 times).[10]

The increase in investment performance is due, among other things, to an increase in the inflow of funds allocated to Uzbekistan by international financial institutions and foreign government financial institutions, The Japanese government's financial institutions - JICA and JBIC (20\% relative to total, or $\$ 470.8$ million), Asian Development Bank (16.6\%, or $\$ 380.0$ million), World Bank (11.2\%, or $\$ 256.8$ million), Islamic Development Bank (3.6\%) (or $\$ 81.2$ million) and other.[11]

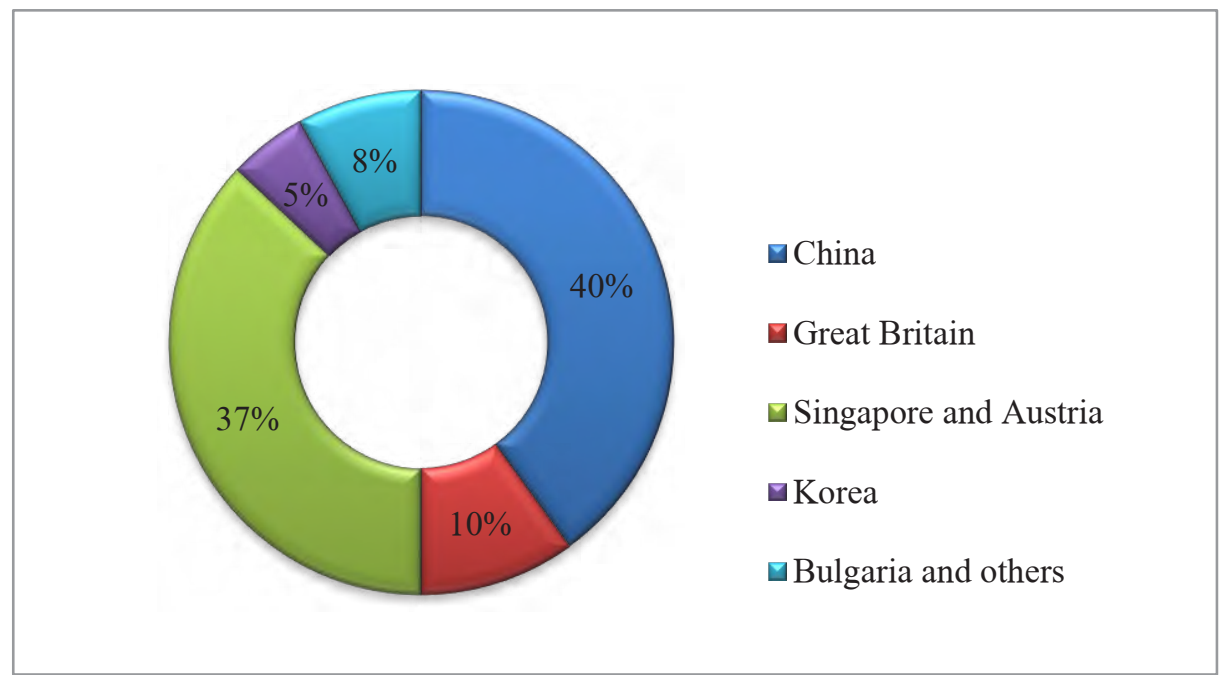

Fig. 4. Countries investing in the SEZ of the Republic of Uzbekistan.

Based on the experience of the Republic of Uzbekistan, the financing of fixed investments is realized at the expense of its own and attracted sources. The most valuable in the structure of their own sources of financing capital investments are depreciation, profit, and other own sources (income from the liquidation of fixed assets, insurance reimbursements, and so on). Investment credit, government subsidies and financial leasing are considered to be attracted sources of capital investment. 
The economies of the world were also affected by the pandemic. Worldwide, the number of newly created investment projects decreased by $37 \%$, mergers and acquisitions by $15 \%$, and the important source of infrastructure investment - cross-border project financing transactions - decreased by $25 \%$.

The greatest impact in the form of reductions in investment is evident in advanced economies. For example, in North America, foreign direct investment decreased by $56 \%$, to $\$ 68$ billion.

China has seen strong performance, and in this regard, the performance in Asia as a whole has decreased by $12 \%$. In the case of the transition economies, foreign investment declined by $81 \%$ due to the sharp decline in Russia.[12]

There are many problems that prevent the effective attraction of foreign investment to the country:

- excessive regulation of foreign economic relations

- regional problems with the use of infrastructure (water, natural gas and electricity)

- somewhat inconvenient location of the country, for European countries, lack of an optimal transport route

- lack of highly qualified workers

- insufficient level of experience in working with investment projects

- passive intervention of local authorities in providing foreign investors with complete information about the investment potential and investment climate of the territories [13]

\section{Conclusions}

From 2018, the "Year of Active Entrepreneurship, Innovative Ideas and Technology" regularly publishes ratings of investment attractiveness of regions. The rating helps to assess the conditions created for investors in the regions of Uzbekistan, among the investors - companies from the United States, Turkey, South Korea, Germany, Russia and Japan.

2019 was held in Uzbekistan under the name "Year of Active Investment and Social Development." In order to conduct an active investment policy, taking into account the regional use of existing resources and the efficient use of resources, including direct investment, investment projects have been developed to strengthen the current and technological rearmament and the formation of new high-tech industries, as well as to ensure employment of citizens on this basis, improving the standard and quality of life of society.

The Ministry of Investment and Foreign Trade was established in the Republic of Uzbekistan, which ensured efficient distribution and targeting of investments, and effectively implemented direct programs for short periods.

With all the improvements in the investment environment, most economic entities are unable to ensure the full direction of their own savings in the investment process. Therefore, it is necessary to improve the mechanism for organizing investment and innovation activities. It is recommended to continuously improve and specify the current regulatory framework, create organizational and administrative structures at the state and regional levels that will be able to introduce innovative technologies at the expense of investment funds. Such structures are: insurance, audit, outsourcing firms, investment and financial organizations, and so on. [14]

It is recommended that relations be built on a competitive basis between the subjects of the investment process in order to maintain closed systemic contacts, and to protect against unfair competition of the investment and innovation sphere. The statistical analysis revealed that important factors in the commercialization of industrial innovations are the availability of a production base, and the availability of the necessary resources to achieve the production of competitive products in the future. The activation of investment 
innovation does not appear without an improvement in the incentive mechanism. One such measure could be tax support for investors. [15]

Another relevant measure can be considered the introduction of a functional system of investment insurance in the field of innovation, which is expressed by tax or state support of insurance companies, ready to accept the risks of innovation. When considering the regional agricultural sector, methodical support is of particular importance when using modern innovative projects.

To intensify the innovation and investment activities of agricultural sector entities it is recommended to use the leasing mechanism in the investment project, it contributes to the renewal of their resource and technical base, to increase the competitiveness of products.

The following measures should be taken to improve the investment policy of states a:

1- Create and improve the regulatory provision of investment activity, tax mechanisms to stimulate it and the introduction of its instruments into economic circulation.

2- Development of the infrastructure of the innovation process, including information support, expertise, financial, economic, production and technology support, certification and promotion of development, training and retraining.

3- Promoting the process of accelerated industrial development of national and foreign scientific and technological achievements of world-class standards, reproduction of natural resources.

As a result, we can say that the above measures to improve investment and innovation activity and the development of the national economy of Uzbekistan contribute to the development of scientific and technological potential, sustainable growth, increasing the competitiveness of the national economy of Uzbekistan, and creating guarantees of the country's economic security in the future.

\section{References}

1. The resolution of the President of the Republic of Uzbekistan "On the forecast of the main macroeconomic indicators and parameters of the state budget of the Republic of Uzbekistan for 2019-2021 and budget guidelines for 2019-2021" (2018)

2. On measures to radically improve the investment climate in the Republic of Uzbekistan. Decree of the President of Uzbekistan No. UP-5495 (2018)

3. On measures to further improve the mechanisms to attract foreign direct investment to the country's economy. Decree of the President of Uzbekistan No. PP-4300 (2019)

4. On the organization of the Ministry of Investment and Foreign Trade of the Republic of Uzbekistan. Decree of the President of Uzbekistan. No PP-4135 (2019)

5. G.S. Seikkasimov, Problems of the modern economy 3/4 (19/20) (2006)

6. A. Navoi, Problems of Economics 11, 63-75 (2018)

7. T.A. Tumina, Russian transport business 1, 46-49 (2009)

8. V.V. Kookueva, Yu.S. Tsertseil, Vektor ekonomiki 8, 17-17 (2018)

9. E. Borensztein, J. De Gregorio, J.W. Lee, Journal of international Economics 45(1), 115-135 (1998)

10. B.P. Bosworth, S.M. Collins, C.M. Reinhart, Brookings Papers on Economic Activity 1999(1), 143 (1999)

11. S. Mallick, T. Moore, Foreign Capital in a Growth Model. Review of Development Economics 12(1), 143-159 (2008)

12. Social and economic position of the Republic of Uzbekistan for 2017 (Tashkent, 2018)

13. L.A. Foreign, Investments. Tutorial (Bookmaker, M., 2010) 
14. S.S. Gulyamov, A.M. Abdullayev, etc., Innovation potential and its impact on the competitive development of the country's economy (theoretical and methodological aspects) (Fan va technology, T., 2016)

15. A.M. Abdullayev and others, Sustainable economic development of Uzbekistan in the conditions of globalization (Fan Va Technology, T., 2016) 